\title{
ПАРОДИЙНЫЙ ПЕРЕСКАЗ ДОН-АМИНАДО ОБ ЭМИГРАЦИИ И ЭМИГРАНТАХ
}

\author{
DON AMINADO'S MOCK NOVELETTE \\ ABOUT EMIGRATION AND EMIGRANTS
}

\author{
ИОАННА МЯНОВСКА
}

\begin{abstract}
Among the group of Russian emigrants in the 20th century, after the October Revolution, were many famous satirists and humorists, for example, A. Averchenko, Sasha Cherny, N. Teffi, V. Goryansky, Don-Aminado and many other acclaimed masters of satire. Attention is focused on a mock novelette about emigration and emigrants that was written by the so-called "new Kozma Prutkov" - a forgotten satire writer Don-Aminado (real name: Aminad Petrovich Shpolyansky). The year 2012 marked the 55th anniversary of his death.

This article examines Don-Aminado's aphorisms and a mock novelette about his fellow countrymen in France. The experience the satirist gained from his wanderings after he had emigrated from Russia let him re-evaluate many things and allowed him to make fun of himself, his friends and the fact that, by a stroke of fortune, they came to Paris. The existence of a "little man", i.e. a Russian emigrant in France, his/her poverty, debts, the privation he/she suffered, the lack of professional job offers and the fact that he/she lived on credit was the major theme in Don-Aminado's satire. Don-Aminado is said to be Kozma Prutkov's successor as regards his poetic parodies, maxims and aphorisms that are applicable to life, which is the secret of their longevity.
\end{abstract}

Joanna Mianowska, Uniwersytet im. Kazimierza Wielkiego w Bydgoszczy, Bydgoszcz - Polska.

В русской послеоктябрьской эмиграции XX века оказались известные сатириконцы и юмористы, а среди них А. Аверченко, Саша Черный, Н. Тэффи, В. Горянский, Н. Агнивцев, Дон-Аминадо и многие другие признанные мастера сатиры. Наше внимание сосредоточим на пародийном пересказе об эмиграции и эмигрантах „нового Козьмы Пруткова", как его называли, Дон-Аминадо (настоящая фамилия - Аминад Петрович vel Аминодав Пейсахович Шполянский), немного забытого сатириконца (в 2012 году прощло 55 лет со дня его смерти)ํ․

1 Л. С п и р и д о н о в а, Дон-Аминадо, [в:] Русское зарубежье. Золотая книга эмиграциии. Первая треть ХХ века. Энцииклопедический биографический словарь, под общ. ред. В. Шелохаева, Москва 1997, с. 221-223. 
Дон-Аминадо удалось в изгнании возродить на краткий период журнал „Сатирикон”, где он подписывался псевдонимом „К. Страшноватенко" 2 . Леонид Зуров так вспоминает всеми любимого Дон-Аминадо 30-х годов в Париже:

[...] молодой, полный решительной, веселой и бодрой уверенности, небольшого роста [...] хорошо очерченный лоб, бледное лицо и необыкновенная [...] меткость слов, сильный и весело-властный голос, а главное - темные, сумрачные глаза, красивые глаза мага и колдуна

Дон-Аминадо - автор стихов, пьес, множества сатирических фельетонов и рассказов, афоризмов, а также книги мемуаров Поезд на третъем пути (1954), которую Г. Адамович назвал „обломком эпохи" 4 . В своей книге воспоминаний Дон-Аминадо воссоздает атмосферу эмигрантского быта и судеб многих литераторов. Этот мастер самоиронии и бытописатель констатирует о своей эмигрантской среде следующее: „[...] Мы создали: свои привычки, свои нравы, свою особую жизнь, мир, быт, порядок, законы, обычаи, партии и учреждения" 5 . Дон-Аминадо отмечал также „неотъемлемый” талант Н. Тэффи, добродушие А. Яблонского, славу и блистательность М. Осоргина, остроумие и даровитость В. Азова. Именитыми и знаменитыми называл М. Алданова, Г. Адамовича, И. Бунина, 3. Гиппиус, Б. Зайцева, А. Куприна и М. Цветаеву и даже евразийского князя Д. Святополка-Мирского

Не случайно Дон-Аминадо считался в эмиграции одним из „чеховских" людей. Обожая Чехова, подражая этому непревзойденному мастеру пародии, Дон-Аминадо напишет о нем: „,[...] вовремя умер человек - до революции, до эмиграции, в городе Баден-Вейлере, в Шварцвальде, на юге Германии"7. Пародия, как отмечает В. Пропп, „[...] смешна только тогда, когда она вскрывает внутреннюю слабость того, что пародируется", и с этим мнением стоит согласиться.

Скитальчество Дон-Аминадо, начавшееся в Константинополе и завершившееся в Париже, дало свои плоды в сатирическом отражении

2 А. 3 в е р е в, Повседневная жизнь русского литературного Парижа 1920-1940, Москва 2003, с. 81.

3 Л. 3 у р о в, Дон-Аминадо, [в:] Дальние берега. Портреты писателей эмиграциии. Мемуары, сост. В. Крейд, Москва 1994, с. 330.

" J. M i a n o w s k a, "Третий путь” Дон-Аминадо к 2009 году, [в:] Русский язык в контексте культуры, сборник научных статей, под общей ред. Т. Михальчук, Могилев 2010, с. 161-166.

5 Д о н - А м и н а д о, Выборы королеъы, „Последние новости” 1928, 5 января.

6 Д о н - А м и н а д о, Поезд на третьем пути, Москва 2000, с. 278.

7 Цит. по: А. И в а н о в, Россия, выехавшая за гранииу, [в:] Д о н - А м и н а д о, Чем ночь темней..., сост., вст. ст. и коммент. А.С. Иванова, Санкт-Петербург-Москва 2000, c. 9.

8 В. П р о п п, Проблемы комизма и смеха, Москва 2002, с. 65. 
эмиграции и эмигрантов. Уже в первом своем парижском сборнике стихов Дым без отечества (1921) появляется чеховская тема „маленького человека" в отношении к русским эмигрантам. Герой Дон-Аминадо разочаровался в революции, его скитальческая жизнь преисполнена мыслями о прошлом, горечью и горестной самоиронией 9 . Быт соотечественников отражен и ярко представлен и в сборнике Наша маленъкая жизнь (1927), где метко показана жизнь русской колонии (близ Булони, как пишет автор) ${ }^{10}$. Сатира Дон-Аминадо и в этом произведении направлена на быт „маленького человека”, русского эмигранта. Зоркий глаз сатирика подмечает слабые стороны исшедших, их лишения, долги, жизнь в кредит, отсутствие работы по профессии. Лаконизм звучит в стихах Дон-Аминадо:

Белошвейка из Москвы

Шьет с ручательством за швы

или

Присяжный стряпчий Кривоногов

Дает советы от налогов,

или

Математик Куприянов

Репетирует болванов ${ }^{11}$.

Стоит отметить, что юмор Дон-Аминадо не был ни обличительным, ни издевательским, вернее всего - он был беззлобным. Русская эмиграция и эмигранты в Нашей маленькой жизни были не на одно лицо. Иногда тупы, глупы, завистливы, были среди них и проходимцы, но эти черты присущи не только эмигрантам и не всегда их надо персонифицировать. Поэтому часто вместо имен и фамилий в двустишиях и четверостишиях Дон-Аминадо имитирует объявления эмигрантов, помещенные в разных газетах и журналах. Они смешны и ироничны, как, например, эти: „Ищут скромного студента, если можно без акцента”; „Молод. Знаю языки. Могу делать шашлыки”; „Собираю ассигнации для архива эмиграции", трагичны: „Продается домик с садом (с крематориумом рядом)”; „Отправляюсь в газовое общество, принимаю поручения" 12 .

Спиридонова справедливо отмечала самую характерную черту всей сатиры русского зарубежья - синтез комического и трагическо-

9 Литературная эницилопедия русского зарубежья 1918-1940, т. 3: Книги, гл. ред. и сост. А. Николюкин, Москва 2002, с. 199-200.

10 Д о н - А м и н а д о, Чем ночь темней..., указ. соч., с. 273.

11 Там же, с. 266, 273.

12 Там же, с. 268, 269, 271, 273, 280. 
го13. Объектом сатиры Дон-Аминадо была окружающая его действительность - это русские эмигранты, живущие в замкнутом русском городке на Сене, в том числе и он сам, пытавшийся оценить себя и других глазами европейца, что обратилось в примесь смеха и печали, как в следующих двустишиях: „Срочно нужен на Европу/Представитель по укропу”; „Рюмка водки и рагу/На нормандском берегу” или „Очень бывшая персона/Ищет должности гарсона”; „Ищут девушку, Матрешку,/Расшибать детей в лепешку"14. Эти бытовые юморески из-за отсутствия в эмиграции цензуры часто превращались в ностальгическую лирику, как, например, в четверостишии:

Вечер смеха и забавы
В память взятия Полтавы
Среди прочих номеров -
Комик Сидоров-Петров 15

или

Русский хутор близ Диканьки,

Есть и собственные баньки -

С паром, с веничком, с кваском,

С осетриною куском...16.

В оценке этих и других пародийных пересказов Дон-Аминадо выделяются такие черты сатирика и его творческой манеры, как лаконизм, афористичность, любовь к каламбуру, острословие, иронический перифраз, сопоставление несовместимых понятий ${ }^{17}$. Пародийный пересказ Дон-Аминадо не имеет своей целью „передразнивать” оригинал какого-либо литературного произведения. Дон-Аминадо пародирует не только эмиграцию, но и советчину, разоблачает ее зло и весь советский уклад жизни. Слова Дон-Аминадо: „Советская присказка: "Да" и „нет" не говорите, серп и молот не воруйте, звезды с неба не хватайте, а налог платите”; „Подходящая пословица для „Ленинградской правды”: Бог „Правду" видит, да не скоро скажет” или „Рабфак и Всеобуч - это реакция на Оксфорд и на Кембридж”18, или „В советской конституции сказано просто: - Три деревни, два села составляют республику, а восемь девок, один я - национальное меньшинство.

13 Л. С п и р и д о н о в а, Сатира русского зарубежья, „Российский литературоведческий журнал", Москва 1994, № 4, с. 41.

14 Д о н - А м и н а д о, Чем ночь темней..., указ. соч., с. 275, 279.

15 Там же, с. 282.

16 Там же, с. 277.

17 Л. С п и р и д о н о в а, Бессмертие смеха. Комическое $\mathrm{b}$ литературе русского зарубежья, Москва 1999, с. 266.

18 Д о н - А м и н а д о, Чем ночь темней..., указ. соч., с. 34, 37, 46. 
- Кто не согласен - может выйти вон. Так как выйти было некуда, все и согласились” 19 , или „Вариант к забытым стихам Кольцова:

$$
\begin{aligned}
& \text { Сяду я за стол, } \\
& \text { Да подумаю, } \\
& \text { Как на свете жить, } \\
& \text { Беспартийному ..."20 }
\end{aligned}
$$

метко и без обиняков передают всю нелепость и трагичность происходящего. В последнем использованы размер и строки стиха А. Кольцова Раздумъя селянина (1837).

Дон-Аминадо, проживая в Париже, выискивал в советской прессе явные несуразицы и умел кратко, лаконично изобличать ложь, используя каламбуры, парадоксы, даже частушки, которые надо считать сугубо русским изобретением, в них каждая строфа автономна. Например:

Все на свете пустяки,

А пальтишко драно...

Все на всете дураки,

Кроме Микояна ${ }^{21}$

или

$$
\begin{aligned}
& \text { Мой миленок, хоть блондин, } \\
& \text { А пропал без вести, } \\
& \text { Ленин пахнет, как жасмин, } \\
& \text { Только с чем-то вместе } 22 .
\end{aligned}
$$

Досталось от сатириконца многим советским знаменитостям. Так, Григорий Зиновьев назван „брюкодержатель русской революции", Крупская - это „бурятский шаман в юбке” 23, а в меню для партийного торжества названы такие блюда, как: „заливное из судака в память Ленина", „бараньи мозги, соус Микояна" и „пончики Коллонтай”"24.

Непритязательный юмор Дон-Аминадо направлен и на его соотечественников во Франции. Опыт эмигрантских скитаний (Константинополь, Париж), проживание в военные годы в Монпелье, Экс-ле-Бене, в Йере, Сен-Себастьяне позволили сатириконцу (он возглавил возобновленный в Париже журнал „Сатирикон” в 1931 году) переоценить многие понятия, способствуя самоиронии. Посмеиваясь над собой, Дон-Аминадо смеялся и над своими товарищами, как и над судьбой, забросившей их в Париж. Этот зоркий наблюдатель напишет: „Сюже рюсс - это человек с душой Александра Блока на петербургской Мой-

\footnotetext{
19 Там же, с. 25.

20 Там же, с. 47.

21 Там же, с. 303.

22 Там же, с. 304

23 Там же, с. 35.

24 Там же, с. 32.
} 
ке и с паспортом, придуманным Фритьофом Нансеном на Женевском озере” 25. В другом месте он скажет: „Русский эмигрант - это чаще всего и принц и нищий в одном переплете" 26 . Зная условия, характер и детали ежедневного быта и бытия русских эмигрантов, Дон-Аминадо отмечает: „Эмиграция напоминает сыр со слезой. Сыр слопан, слеза осталась” 27 и далее: „Лицо эмигранта - это посмертная маска, сделанная при жизни” 28 или „Когда Галилей сказал: „А все-таки она вертится", то имел он в виду не планету, а эмиграцию" 29.

Сатирик воссоздает в краткой форме свои мысли, обогащенные опытом пребывания в новой стране: „Про русскую эмиграцию еще Маркс сказал, что терять ей нечего, а приобрести она может все в рассрочку" 30 . Напомним, что о „русском Париже” писали все эмигранты. Иначе отражали его, к примеру, Н. Берберова, 3. Шаховская, И. Одоевцева или Н. Тэффи ${ }^{31}$. Из названных лишь Берберова обожала Париж, считая, что „[...] этот город насыщен смыслом больше, чем Лондон, Мадрид, Стокгольм и Москва, почти так же, как Петербург, Нью-Йорк и Рим" 32.

Ландшафт самого Парижа для Дон-Аминадо и выстраиваемых им в сатирических произведениях эмигрантах не имел большого значения. Дон-Аминадо писал прежде всего о своих знакомых, друзьях и проблемах изгнанничества, с которыми они - и он сам - сталкивались. Его ненавязчивый, мягкий юмор был даром. О Париже Дон-Аминадо среди многих оценок внимания заслуживает эта:

Русский Париж - это небольшой город, в котором есть все, кроме губернатора. Русские клубы, русские газеты, русские рестораны, русские десятые доли и лотереи, русский Народный университет, русский Красный Крест, русский театр и даже русский дансинг с настоящим русским джаз-бандом. Все есть и все русское. За исключением тюрьмы и кладбища, которые - французские ${ }^{33}$.

25 Там же, с. 23. По инициативе Нансена в 1926 году Лига Наций ввела паспорта для беженцев из России, которые не пользовались покровительством СССР и не стали гражданами другой страны. За „нансановский паспорт” - пошлина 5 франков в год.

26 Там же, с. 23.

27 Там же, с. 40.

28 Там же, с. 53.

29 Там же, с. 56.

30 Там же, с. 54.

${ }^{31}$ Н. Б е р б е р о в а, Курсиъ мой, Москва 1996; И. О д о е в ц е в а, На берегах Неъы, на берегах Сены, Москва 2007; 3. Ш а х о в с к а я, Таков мой Век, Москва 2006; Н. Т э ффи, Моя летопись, Москва 2005.

32 Н. Б е р б е р о в а, указ. соч., с. 162.

33 Д о н - А м и н а д о, Чем ночь темней..., указ. соч., с. 55. 
Дон-Аминадо знал и понимал затруднения в жизни русских во Франции. В его пересказах часто имеют место сравнения русских с французами, их благополучием и материальным обеспечением, различиями в их менталитете, и в этой связи появляются опять же лаконичные, но меткие сатирические констатации типа: „Русские в экспрессе уезжают в Жюан-ле-Пет, а французы пешком ходят в сберегательную кассу” 34 или „Когда два француза говорят об одном градусе мороза, то они до такой степени жестикулируют и волнуются, что со стороны можно подумать: это они репетируют Федру или, по крайней мере, Рюи-Блаз" 35; „На одних сульвупле далеко не уедешь” $36 ;$ „Лучше, когда человека посылают по-русски, чем высылают по-французски" 37.

Стоит отметить, что в пародийных пересказах Дон-Аминадо высказывается на многие злободневные политические темы о происходящем в Советской России, в Париже, в Америке, в Испании и в других странах, однако многие из них можно применить и к нынешнему времени, хотя изменились страхи и болезни современной цивилизации. На наш взгляд, пародийный пересказ и изречения Дон-Аминадо - это своеобразное орудие самоанализа культуры XX века. Чего стоит хотя бы такое изречение: „В Европе маразм, кризис, банкротство, ликвидация... а у русских - блины, щи, борщи, вечеринки, поминки, объединение, чай, сахар... и такое столпотворение у вешалки, что диву даешься!"38 или „Запуганное воображение: - Для вступления в гражданский брак с немкой какая нужна виза? Обыкновенная или транзитная?" 39.

Современны изречения Дон-Аминадо типа: „До чего у европейского человека все просто! Вместо хованщины - крематорий. Вместо кружковщины - клуб. Вместо хождения в народ - трамвай"40. Случаются и предостережения: „В Европе людей называют либо по имени, либо по фамилии, но ни в каком случае не по отчеству. Делается это из предосторожности: - чтоб, [...], сохрани Бог, не нарваться на Ильича" 41. Дон-Аминадо без приемов условности переосмысливает происходящее, метко оценивая парадоксы злободневности, что особо касается его исшедших соотечественников и самого явления эмиграции:

В эмиграции было три пятилетки...

Первая ушла на то, чтобы выяснить, кто с кем живет,

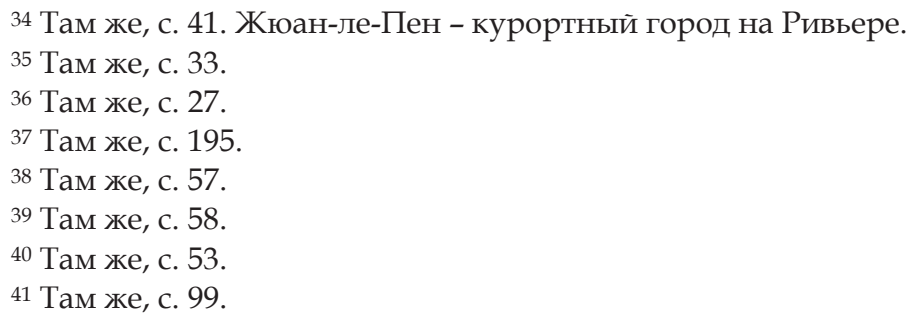


Вторая - кто сколько проживет,

Третья - кого и на что будут хоронить ${ }^{42}$

или:

В России счет ведется на пятилетки,

В эмиграции - на земские давности ${ }^{43}$,

или:

За пятнадцать лет эмиграции были три пятилетки.

Первая - в пользу нуждающихся в отдыхе.

Вторая - в пользу нуждающихся в операции.

Третья - в пользу нуждающихся в погребении ${ }^{44}$.

В альбоме пародий Дон-Аминадо имитируются прежде всего высшие признаки жизненных явлений, ситуаций и обстоятельств. В. Пропп справедливо отмечает:

Пародировать можно решительно все: движения и действия человека, его жесты, походку, мимику, речь, профессиональные привычки и профессиональный жаргон; можно пародировать не только человека, но и то, что им создано в области материального мира ${ }^{45}$.

Пародирование Дон-Аминадо направлено на разнообразные явления, связанные с эмиграцией, например с ее литературно-художественными журналами: „Хоть «Современные записки», а современников - то нет". Или другой пример:

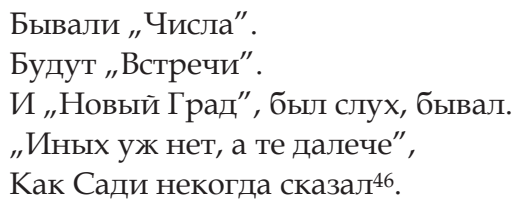

Здесь в последнем четверостишии Дон-Аминадо приводит цитату из поэмы ЕВгений Онегин А. Пушкина (глава 8, LI). Хотя литературные пародии не свойственны сатире Дон-Аминадо, однако появляются пародийные пересказы, в которых совмещается пародия бытовая с литературной цитатой. О русском эмигранте Дон-Аминадо пишет:

То верит в слово, то в дубину-с,

То Августин, то Флоридор

В нем все двоится... Мир и личность.

42 Там же, с. 289.

43 Там же, с. 53.

44 Там же, с. 146.

45 В. П р о п п, Проблемы комизма..., указ. соч., с. 62.

46 Д о н - А м и н а д о, Чем ночь темней..., указ. соч., с. 343. 
И далее:

$$
\begin{aligned}
& \text { Его кредит, его наличность } \\
& \text { И даже логика сама } \\
& \text { И оттого и происходит } \\
& \text { Что он на месте не стоит: } \\
& \text { „Идет налево - песнь заводит, } \\
& \text { Направо - сказку говорит”. }
\end{aligned}
$$

Здесь налицо немного измененная цитата из пролога к поэме Руслан и Людмила, а также ссылки на оперетту Ф. Эрве Мадемуазель Нитуи, где один персонаж выступал в двух лицах и под двумя именами ${ }^{47}$.

В другом месте сатирик, пародируя пожилых, седых и с одышкой эмигрантов, использует и обыгрывает строки из стихотворения М.Ю. Лермонтова Смерть поэта. Переделывая лермонтовское: „С свинцом в груди и жаждой мести”, Дон-Аминадо так пишет об эмигранте:

$$
\begin{aligned}
& \text { Дороден. Тучен. Весь в проборе. } \\
& \text { С шнуром в пенсне. С винцом в груди. } \\
& \text { С веселой искоркой во взоре } \\
& \text { И с длинным прошлым позади } 48 .
\end{aligned}
$$

В одном из пародийных пересказов Дон-Аминадо использует немного измененную им цитату из повести И. Тургенева Отцы и дети и вместо „Природа не храм, а мастерская" сатирик об эмигрантской жизни напишет:

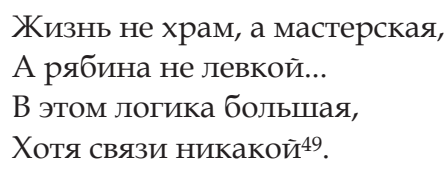

Дон-Аминадо в своих пародийных пересказах осмеивает и стилизует названия пьес. Например, пьеса Катенька, написанная для театра миниатюр П. Потемкиным, так озвучена в четверостишии сатирика в контексте эмиграции:

$$
\begin{aligned}
& \text { - С кем танцуешь, Катенька? } \\
& \text { - С эмигрантом, маменька! } \\
& \text { - Что танцуешь, Катенька? } \\
& \text { - Дан-макабр, маменька!50. }
\end{aligned}
$$

Пессимизм звучит и в другом четверостишии:

Грустно только, что в обрез

Дали нам планету,

\footnotetext{
47 Там же, с. 344-345.

48 Там же, с. 347, выделено мною - И. М.

49 Там же, с. 350.

50 Там же, с. 349. Дан-макабр - пляска смерти.
} 
И что, кроме Пер-Лашез,

Направлений нету 51 .

Известный во времена Дон-Аминадо в Париже русский бас с мировым именем, Федор Шаляпин, исполнял не только главные оперные арии, но и романсы ${ }^{52}$. Дон-Аминадо обыгрывает в ряде своих пародийных пересказов рефрен из стихотворения А. Майкова Менестрель (Провансальский романс) (1859) - „Молчите, проклятые струны”. В шести четверостишиях четыре раза он повторяет „молчите, проклятые струны” и два раза - „Проклятые струны”. На самом деле существовала грамзапись Ф. Шаляпина „Молчите, проклятые струны” 53.

Стоит отметить, что Дон-Аминадо часто использует в пародийных пересказах музыкальные строки, например, из романса на слова Е. Баратынского Разуверение - „Не искушай меня без нужды...”:

Не искушай меня без нужды,

Не ври за совесть и за страх!

Разочарованному чужды -

Корреспонденты на местах...54.

Сатирик переделывает также слова из Русской песни Н. Ибрагимова, и вместо „С милым рай и в шалаше”появляются „С милой рай и в шалаше" 55 .

Стоит, наконец, обратиться к заглавию книги Дон-Аминадо Чем ночь темней..., ибо оно также связано с эмиграцией. У сатирика сказано: „Чем ночь темней, тем гвозди ярче”56. Эта цитата из цикла стихов А. Майкова Из Аполодора Гностика со строкой „Чем ночь темней, тем ярче звезды...". В 20-е годы в Париже известность получили т.н. passage clouté (пассаж-клуте) - „переходы, обитые гвоздями”. В комментариях это объяснено следующим образом:

[...] металлические круги, забитые в асфальт, напоминали шляпки гвоздей. Многие переходы были не освещены, [...] „гвозди” не были видны автомобилистам ${ }^{57}$.

51 Там же, с. 351.

52 Л. С а б а н е е в, Воспоминания о России, Москва 2005; О Ф. Шаляпине см: К. К о р о в и н, Шаляпин. Встречи и совместная жизнь, [в:] „То было давно... там... в России...". Воспоминания, рассказы, письма: в двух книгах, сост., вст. статья Т. Ермолаевой, кн. 2, Москва 2011.

53 Д о н - А м и н а д о, Чем ночь темней..., указ. соч., с. 353.

54 Там же, с. 324.

55 Там же, с. 325.

56 Там же, с. 23.

57 Там же, с. 419. 
Подытоживая сказанное, хочется отметить, что Дон-Аминадо - это преемник Козьмы Пруткова, его стихотворных пародий, максим и афоризмов, обращенных к жизни. Пародийный пересказ Дон-Аминадо в парижской эмиграции позволил не только выхватить и запечатлеть разные явления повседневности исшедших в XX веке, но и развеял некие иллюзии, не только касающиеся эмигрантского сознания, но и общей российской судьбы. Дон-Аминадо, много предвидевший и угадавший, любил повторять: „Не сильвуплюй, говори по-русски!”58.

58 Там же, с. 101. 
